\title{
The effectiveness of tactical management practices in the construction companies
}

\author{
Bldr Chidozie J.Ezenwata * \\ Department of Building Technology, Federal Polytechnic, Oko, Anambra State, Nigeria.
}

GSC Advanced Engineering and Technology, 2021, 02(01), 001-010

Publication history: Received on 10 September 2021; revised on 20 October 2021; accepted on 22 October 2021

Article DOI: https://doi.org/10.30574/gscaet.2021.2.1.0041

\begin{abstract}
This work provides an overview tactics with the intention to analyze and to evaluate effectiveness of strategic management practices in construction companies. In order to achieve this, relevant studies were examined and reviewed on the issues of management practices and construction companies. The research method used is the application of statistical tools in SPSS and Minitab tools to evaluate and to analysis the distributed questionnaires. The aim of the research design is the desire to simplify the complex issue of the strategic management practices, in construction companies in decision making for a better understanding. 349 responses were used to study the population of the construction companies' staff in the case study. The primary and secondary data are the sources of data used for this research. The instruments used in collection of the data were structured questionnaire, interview and observation. The descriptive method was used to analyze the data generated for the research. This was supported by tables showing questions, responses, frequency and percentages. The mean scores, correlation, and standard deviation test was used in analyzing the data generated for the study. The findings indicate that the effectiveness of management practices tactics are highly essential, influential and significance in construction companies. Without adequate tactical management practices, construction companies will have deficiencies in design, construction and construction management. Based on the above findings the researcher made recommendations that will help to enhance construction companies and construction management and to create effectiveness that will enable the environment specifically in construction companies.
\end{abstract}

Keywords: Pearson correlation; Standard deviation; Statistics; Tactical management; Organization; Construction; Companies

\section{Introduction}

This research is to understand the need of management practices in construction companies. It will help to reveal more on the tactics, the essentiality and the necessity of management practices. The effectiveness of the tactics for management practices are highly influential and significance in construction, procurement options, design, building, engineering, maintenance, inventions and life. The need for effective management practices is not just for construction companies but for every day activities in life (Ezeliora, Nwakobi \& Aguh, 2017; Ezeliora, Okoye \& Mbabuike, 2019; Ezeliora et al., 2014; Ezeliora, Umeh \& Dilinna, 2020).

The aim of this research is to study the effectiveness of tactical management practices in construction companies.

\subsection{Research Questions}

- Is there any benefit of strategic management practices in construction companies

- What is the effect of portfolio analysis on performance of construction companies

${ }^{*}$ Corresponding author: Bldr Chidozie J. Ezenwata

Department of Building Technology, Federal Polytechnic, Oko, Anambra State, Nigeria.

Copyright (C) 2021 Author(s) retain the copyright of this article. This article is published under the terms of the Creative Commons Attribution Liscense 4.0. 
- Is there any motivational impact as a management tactics in construction companies

- Is there any benefit in adoption of corporate strategic management practices in construction companies

\subsection{Hypothesis of the Study}

- $\mathrm{H}_{\mathrm{i}}$ : The benefit of strategic management practices are significance in construction companies.

- $\mathrm{H}_{0}$ : To study the benefit of strategic management practices are not significance in construction companies.

- $\mathrm{H}_{\mathrm{i}}$ : There is significance effect of portfolio analysis on performance of construction companies.

- $\mathrm{H}_{\mathrm{o}}$ : There is no significance effect of portfolio analysis on performance of construction companies.

- $H_{\mathrm{i}}$ : The motivational impact as a management tactics are significance in construction companies.

- $\mathrm{H}_{0}$ : The motivational impact as a management tactics are not significance in construction companies.

- $\mathrm{H}_{\mathrm{i}}$ : The benefits in adoption of corporate strategic management practices are significance in construction companies.

- $\mathrm{H}_{0}$ : The benefits in adoption of corporate strategic management practices are not significance in construction companies.

\section{Strategic management}

Strategic management involves the formulation and implementation of the major goals and initiatives taken by a company's top management on behalf of owners, based on consideration of resources and an assessment of the internal and external environments in which the organization competes (Ezeliora, Nwakobi \& Aguh, 2017; Ezeliora et al., 2014; Ezeliora, Umeh \& Dilinna, 2020).

Strategic management provides overall direction to the enterprise and involves specifying the organization's objectives, developing policies and plans designed to achieve these objectives and then allocating resources to implement the plans. Academics and practicing managers have developed numerous models and frameworks to assist in strategic decision making in the context of complex environments and competitive dynamics (Ghemawat, 2002). Strategic management is not static in nature; the models often include a feedback loop to monitor execution and inform the next round of planning (Hill, 2002; Lamb, 1984)

(Porter, 1996), identifies three principles underlying strategy: creating a "unique and valuable [market] position", making trade-offs by choosing "what not to do", and creating "fit" by aligning company activities with one another to support the chosen strategy. Kotter, (1982), defines strategy as "a system of finding, formulating, and developing a doctrine that will ensure long-term success if followed faithfully".

Corporate strategy involves answering a key question from a portfolio perspective: "What business should we be in?" Business strategy involves answering the question: "How shall we compete in this business" (Chaffee, 1985). In management theory and practice, a further distinction is often made between strategic management and operational management. Operational management is concerned primarily with improving efficiency (Ezeliora, Nwakobi \& Aguh, 2017; Ezeliora, Okoye \& Mbabuike, 2019; Ezeliora et al., 2014; Ezeliora, Umeh \& Dilinna, 2020) and controlling costs within the boundaries set by the organization's strategy.

Strategic management involves the related concepts of strategic planning and strategic thinking. Strategic planning is analytical in nature and refers to formalized procedures to produce the data and analyses used as inputs for strategic thinking, which synthesizes the data resulting in the strategy. Strategic planning may also refer to control mechanisms used to implement the strategy once it is determined. In other words, strategic planning happens around the strategic thinking or strategy making activity (Mintzberg, 1996).

Strategic management is often described as involving two major processes: formulation and implementation of strategy. While described sequentially below, in practice the two processes are iterative and each provides input for the other (Mintzberg, 1996).

\subsection{Strategic Management and Strategy Execution}

Strategic management is the comprehensive collection of ongoing activities and processes that organizations use to systematically coordinate and align resources and actions with mission, vision and strategy throughout an organization. Strategic management activities transform the static plan into a system that provides strategic performance feedback to decision making and enables the plan to evolve and grow as requirements and other 
circumstances change.Strategy Execution is basically synonymous with Strategy Management and amounts to the systematic implementation of a strategy.

\subsection{Construction}

In large construction projects, such as this skyscraper in Melbourne, Australia, cranes are essential. Construction is the process of constructing a building or infrastructure (Compare, 2016) Construction differs from manufacturing in that manufacturing typically involves mass production of similar items without a designated purchaser, while construction typically takes place on location for a known client (Halpin et al, 2010). Construction as an industry comprises six to nine percent of the gross domestic product of developed countries (Chitkara, 1998). Construction starts with planning, design, and financing; and continues until the project is built and ready for use.

Large-scale construction requires collaboration across multiple disciplines. An architect normally manages the job, and a construction manager, design engineer, construction engineer or project manager supervises it. For the successful execution of a project, effective planning is essential. Those involved with the design and execution of the infrastructure in question must consider zoning requirements, the environmental impact of the job, the successful scheduling, budgeting, construction-site safety, availability and transportation of building materials, logistics, inconvenience to the public caused by construction delays and bidding, etc. The largest construction projects are referred to as megaprojects.

\subsection{Construction processes}

In the modern industrialized world, construction usually involves the translation of designs(Ezeliora, Okoye \& Mbabuike, 2019; Ezeliora, Umeh \& Dilinna, 2020) into reality. A formal design team may be assembled to plan the physical proceedings, and to integrate those proceedings with the other parts. The design usually consists of drawings and specifications, usually prepared by a design team including Architect, civil engineers, mechanical engineers, electrical engineers, structural engineers, fire protection engineers, planning consultants, architectural consultants, and archaeological consultants. The design team is most commonly employed by the property owner. Under this system, once the design is completed by the design team, a number of construction companies or construction management companies may then be asked to make id for the work, either based directly on the design, or on the basis of drawings and a bill of quantities provided by a quantity surveyor. Following evaluation of bids, the owner typically awards a contract to the most cost efficient bidder. The modern trend in design is toward integration of previously separated specialties, especially among large firms. In the past, architects, interior designers, engineers, developers, construction managers, and general contractors were more likely to be entirely separate companies, even in the larger firms. Presently, a firm that is nominally "architecture" or "construction management" firm may have experts from all related fields as employees, or to have an associated company that provides each necessary skill. Thus, each such firm may offer itself as "one-stop shopping" for a construction project, from beginning to end. This is designated as a "design build" contract where the contractor is given a performance specification and must undertake the project from design to construction, while adhering to the performance specifications (Ezeliora, Nwakobi \& Aguh, 2017; Ezeliora et al., 2014). Several project structures can assist the owner in this integration, including design-build, partnering and construction management. In general, each of these project structures allows the owner to integrate the services of architects, interior designers, engineers and constructors throughout design and construction. In response, many companies are growing beyond traditional offerings of design or construction services alone and are placing more emphasis on establishing relationships with other necessary participants through the design-build process (Ezeliora, Nwakobi \& Aguh, 2017; Ezeliora, Okoye \& Mbabuike, 2019; Ezeliora et al., 2014; Ezeliora, Umeh \& Dilinna, 2020). The increasing complexity of construction projects creates the need for design professionals trained in all phases of the project's life-cycle and develop an appreciation of the building as an advanced technological system (Ezeliora, Umeh \& Dilinna, 2020) requiring close integration of many sub-systems and their individual components, including sustainability. Building engineering is an emerging discipline that attempts to meet this new challenge.

\section{Research Method}

\subsection{Research Design}

By verture of the nature of the research, survey research method was adopted for this research. Survey research method according to Ogunoh et al., (2014) is one in which group of people or items are studied by collecting and analyzing data from only few people or items considered to be representative of entire group. The use of survey research method makes the data generated directly from respondents to be more distinct and finite. 


\subsection{Types and Sources of Data}

Data for the research was sourced through primary and secondary data. They were collected expressly to help solve the research problems.

\subsection{Questionnaire}

A total of three hundred and forty nine (349) questionnaires were distributed to staff and stakeholders by the researcher and research assistants by hand. Out of the 349 questionnaires, distributed, 320 were returned which is $92 \%$ response rate while 29 were not returned which is $8 \%$ response rate.

\subsection{Population of the Study}

Preliminary survey of the study revealed that a total of twelve (12) construction companies, comprising of four (4) in Awka, three (3) in Nnewi, three (3) in Onitsha and two (2) in Ekwulobia were in the study area.

Therefore, the population for this study includes twelve (12) construction companies in the study, 290 staff and 30 stakeholders that have gained adequate knowledge and experience of both maintenance management and condition of buildings in the university.

\subsection{Determination of Sample Size}

The sample size for this study was determined using Bouely's formular as cited in Ogunoh et al., (2014).

$\mathrm{n}=\frac{N}{1+N(e)^{2}}$

Where $\mathrm{n}=$ sample size, $\mathrm{N}=$ population

$\mathrm{e}^{2}=$ Margin of error (assumed 5\%), 1 = unity or constant

Therefore $=\frac{2750}{1+2750(0.05)^{2}}$

$\frac{2750}{1+(2750 \times 0.0025)}=\frac{2750}{1+6.875}$

$\frac{2750}{7.875}=349$

The sample size of 349 was adopted for this study.

\section{Data Presentation and Analysis}

\subsection{Distribution of Questionnaire}

Table 1 Distribution of Questionnaires

\begin{tabular}{|l|c|c|c|c|c|c|}
\hline \multirow{2}{*}{ Group } & \multicolumn{5}{|c|}{ Campuses } \\
\cline { 2 - 8 } & Awka & Nnewi & Onitsha & Ekwulobia & Total & \% \\
\hline Casual Staff & 41 & 23 & 31 & 37 & 132 & 41.25 \\
\hline Mechanical and Civil Engineering Department & 13 & 16 & 24 & 8 & 61 & 19.06 \\
\hline Management Unit & 17 & 9 & 19 & 4 & 49 & 15.31 \\
\hline Asphalt and Crush stone Department & 13 & 13 & 15 & 7 & 48 & 15 \\
\hline Stakeholders & 10 & 3 & 11 & 6 & 30 & 9.38 \\
\hline & \multicolumn{2}{|l|}{ Sub Total } & & 320 & $100 \%$ \\
\hline
\end{tabular}

Source: Researcher's field study (2021) 
Table 1 shows that out of 320 responses, 132 (that is $41.25 \%$ ) of the casual staff responded to the questionnaires distributed in the areas under study. Out of 320 responses, 61 that is $19.06 \%$ of Mechanical and Civil Engineers responded to the questionnaires distributed. Out of 320 responses, 49 responses that is $15.31 \%$ of management units responded to the questionnaires distributed. Out of 320 responses, 48 responses, that is $15 \%$ of Asphalt and Crush stone staff responded to the questionnaires distributed and out of the 320 responses, 30 (that is 9.38\%) of Stakeholders responded to the questionnaires distributed.

Table 2 Return Rate of Questionnaire

\begin{tabular}{|l|c|c|}
\hline Questionnaire & Frequency & $\begin{array}{l}\text { Percentage } \\
\text { (\%) }\end{array}$ \\
\hline $\begin{array}{l}\text { Total No of Questionnaire Administered to the construction } \\
\text { staff and stakeholders of Construction Companies }\end{array}$ & 349 & 100.00 \\
\hline No of Questionnaire Received & 320 & 92 \\
\hline No of Questionnaire not Received & 29 & $100 \%$ \\
\hline Total & & \\
\hline \multicolumn{2}{|c|}{ Source: Researchers field study 2021 } \\
\hline
\end{tabular}

\subsection{Number of Questionnaire Distributed and Returned}

Table 2 shows that a total number of 349 questionnaires were distributed to construction staff and stakeholders based on a stratified random sampling. Out of the 349 questionnaires distributed, 320 were completed and returned which corresponds to a response rate of $92 \%$. The response rate was high because research assistants were used by the researcher in distributing and returning the questionnaire. The response rate of $92 \%$ is therefore reasonably high and adequate for the study. The rest of the questionnaire were either not properly completed or returned uncompleted. The ones not properly completed were disregarded because they were not usable. No reason was given by the respondents for the uncompleted questionnaire. Table 4.2 shows the population distribution of respondents and the percentage response to the questionnaires by staff and stakeholders.

Table 3 Population Distribution of Questionnaires and Percentage Response for staff and stakeholders

\begin{tabular}{|l|c|c|c|}
\hline Staff and stakeholders & $\begin{array}{l}\text { No of Questionnaire } \\
\text { Distributed }\end{array}$ & $\begin{array}{l}\text { No of Questionnaires } \\
\text { Received(Response) }\end{array}$ & $\begin{array}{l}\text { Percentage Contribution } \\
\text { to Total Response }\end{array}$ \\
\hline Construction workers & 180 & 173 & 54.06 \\
\hline Site Supervisors & 49 & 43 & 13.44 \\
\hline Project Managers & 38 & 33 & 10.31 \\
\hline Companies Stakeholders & 30 & 25 & 7.81 \\
\hline Other company's Staff & 52 & 46 & 14.38 \\
\hline Total & 349 & 320 & $100 \%$ \\
\hline
\end{tabular}

Source: Researchers field study 2021

\subsection{Response Rate of Questionnaire}

Table 3 shows that, the questionnaires distributed to construction workers were 180, out of which 173 were retuned representing $54.06 \%$ of the total response. 49 were distributed to Site Supervisors and 43 were returned representing $13.44 \%$. Project Managers had 38 out of 33 questionnaire returned representing 10.31\% of the total response. 30 were distributed to Companies Stakeholders and 25 were returned which represented $7.81 \%$. While the remaining 52 were distributed to other company's Staff, out of which 46 were returned representing $14.38 \%$. This shows that the majority of the respondents are construction workers, which gives a fair representation of the construction staff and stakeholders proportion in the Nigerian Construction companies. 
Table 4 Respondents Opinion on the Strategic Management Practices in Construction Companies

\begin{tabular}{|l|l|l|l|c|c|c|c|c|}
\hline S/N & Factors & $\begin{array}{l}\text { Strongly } \\
\text { agree(5) }\end{array}$ & $\begin{array}{l}\text { Agree } \\
\text { (4) }\end{array}$ & $\begin{array}{l}\text { Strongly } \\
\text { Disagree } \\
\text { (3) }\end{array}$ & $\begin{array}{l}\text { Disagree } \\
\text { (2) }\end{array}$ & $\begin{array}{l}\text { Don't } \\
\text { Know(1) }\end{array}$ & $\begin{array}{l}\text { Mean } \\
\text { score }\end{array}$ & Rank \\
\hline 1 & $\begin{array}{l}\text { benefit of strategic } \\
\text { management in } \\
\text { practices } \\
\text { construction } \\
\text { companies }\end{array}$ & 115 & 171 & 3 & 30 & 1 & 4.153125 & 4 \\
\hline 2 & $\begin{array}{l}\text { the effect of portfolio } \\
\text { analysis on } \\
\text { performance of } \\
\text { construction } \\
\text { companies }\end{array}$ & 187 & 111 & 20 & 2 & 0 & 4.509375 & 5 \\
\hline 3 & $\begin{array}{l}\text { motivational impact } \\
\text { as a management } \\
\text { tactics in } \\
\text { construction } \\
\text { companies }\end{array}$ & 97 & 193 & 18 & 9 & 3 & 4.1625 & 4 \\
\hline 4 & $\begin{array}{l}\text { benefitin adoption of } \\
\text { corporate strategic } \\
\text { management } \\
\text { practices } \\
\text { construction in } \\
\text { companies }\end{array}$ & 154 & 123 & 29 & 11 & 3 & 4.29375 & 4 \\
\hline
\end{tabular}

\subsection{Opinions on the Factors Leading to Strategic Management Practices in Construction Companies}

Table 4 represents ranking of four (4) significant factors leading to Strategic Management Practices in Construction Companies. The result revealed the significance of tactical Management Practices in Construction Companies. The significance benefit of strategic management practices in construction companies ranked first among the factors with mean scores of 4.15 followed by the significance the effect of portfolio analysis on performance of construction companies with mean scores of 4.51 . The motivational impact as a management tactics in construction companies ranked third, with mean scores of 4.16. The current benefit in adoption of corporate strategic management practices in construction companies ranks forth on the list with mean score of 4.29. This implies that there is a high significance on the effectiveness of tactical management practices on the performance of construction companies.

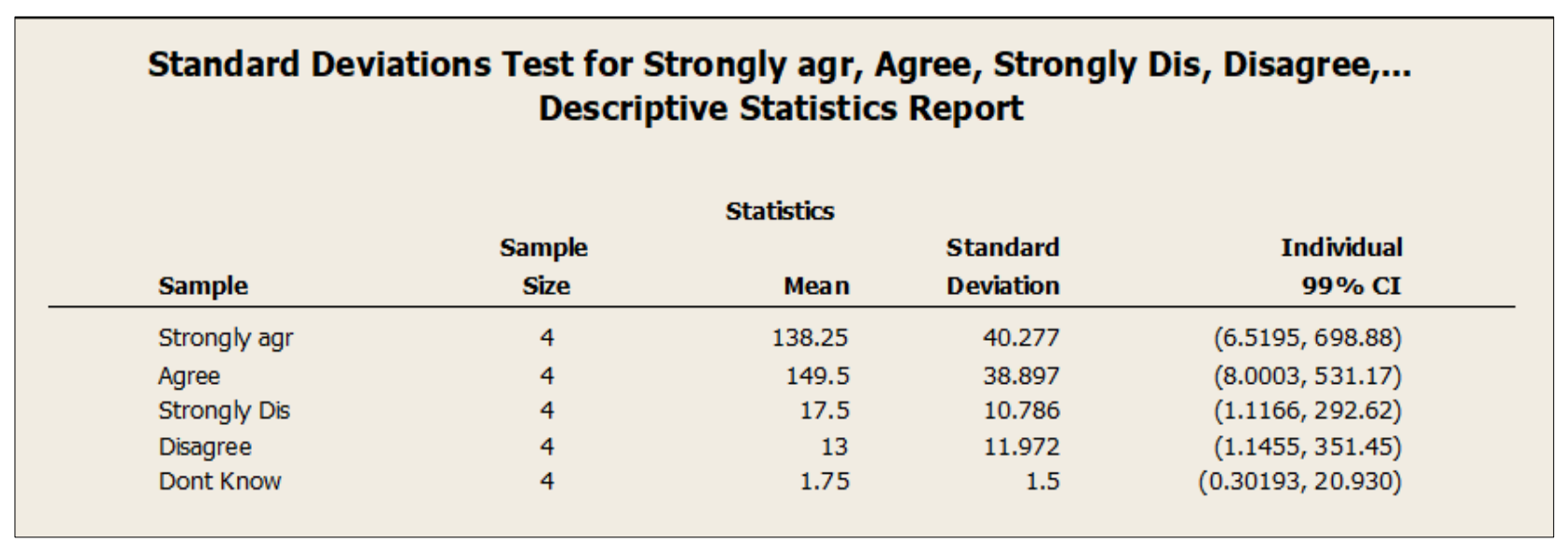

Figure 1 Descriptive Statistics Report for Standard Deviations Test 
Figure 1 shows the descriptive statisticsreport for the standard deviations test. The statistical method was used to analyze the parameters. The analysis ensures the confidence level and statistics of the tested parameter which revealed the confidence level of the parameters.

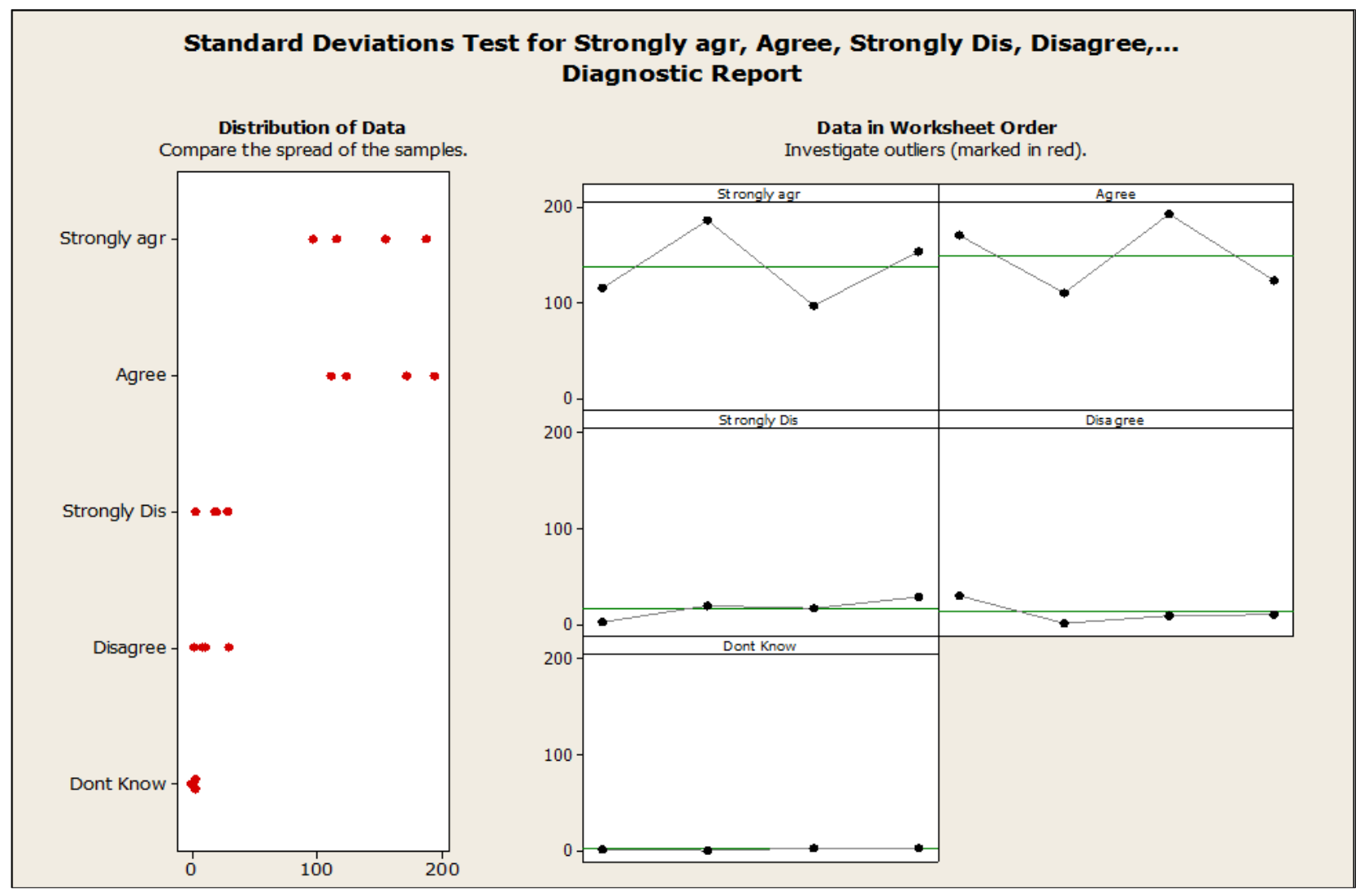

Figure 2 Diagnostic Report for Standard Deviations Test

Table 5 Pearson Correlations

\begin{tabular}{|l|l|c|c|c|c|c|}
\hline \multicolumn{2}{|l}{} & Strongly Agree & Agree & Strongly Disagree & Disagree & Don't Know \\
\hline \multirow{4}{*}{ Strongly Agree } & Pearson Correlation & 1 & $-0.976^{*}$ & 0.475 & -0.552 & -0.550 \\
\cline { 2 - 7 } & Sig. (2-tailed) & & 0.024 & 0.525 & 0.448 & 0.450 \\
\cline { 2 - 7 } & $\mathrm{N}$ & 4 & 4 & 4 & 4 & 4 \\
\hline \multirow{5}{*}{ Agree } & Pearson Correlation & $-0.976^{*}$ & 1 & -0.549 & 0.478 & 0.414 \\
\cline { 2 - 7 } & Sig. (2-tailed) & 0.024 & & 0.451 & 0.522 & 0.586 \\
\cline { 2 - 7 } & N & 4 & 4 & 4 & 4 & 4 \\
\hline \multirow{5}{*}{ Strongly Disagree } & Pearson Correlation & 0.475 & -0.549 & 1 & -0.772 & 0.443 \\
\cline { 2 - 7 } & Sig. (2-tailed) & 0.525 & 0.451 & & 0.228 & 0.557 \\
\cline { 2 - 7 } & N & 4 & 4 & 4 & 4 & 4 \\
\hline \multirow{5}{*}{ Disagree } & Pearson Correlation & -0.552 & 0.478 & -0.772 & 1 & -0.019 \\
\cline { 2 - 7 } & Sig. (2-tailed) & 0.448 & 0.522 & 0.228 & & 0.981 \\
\cline { 2 - 7 } & N & 4 & 4 & 4 & 4 & 4 \\
\hline
\end{tabular}




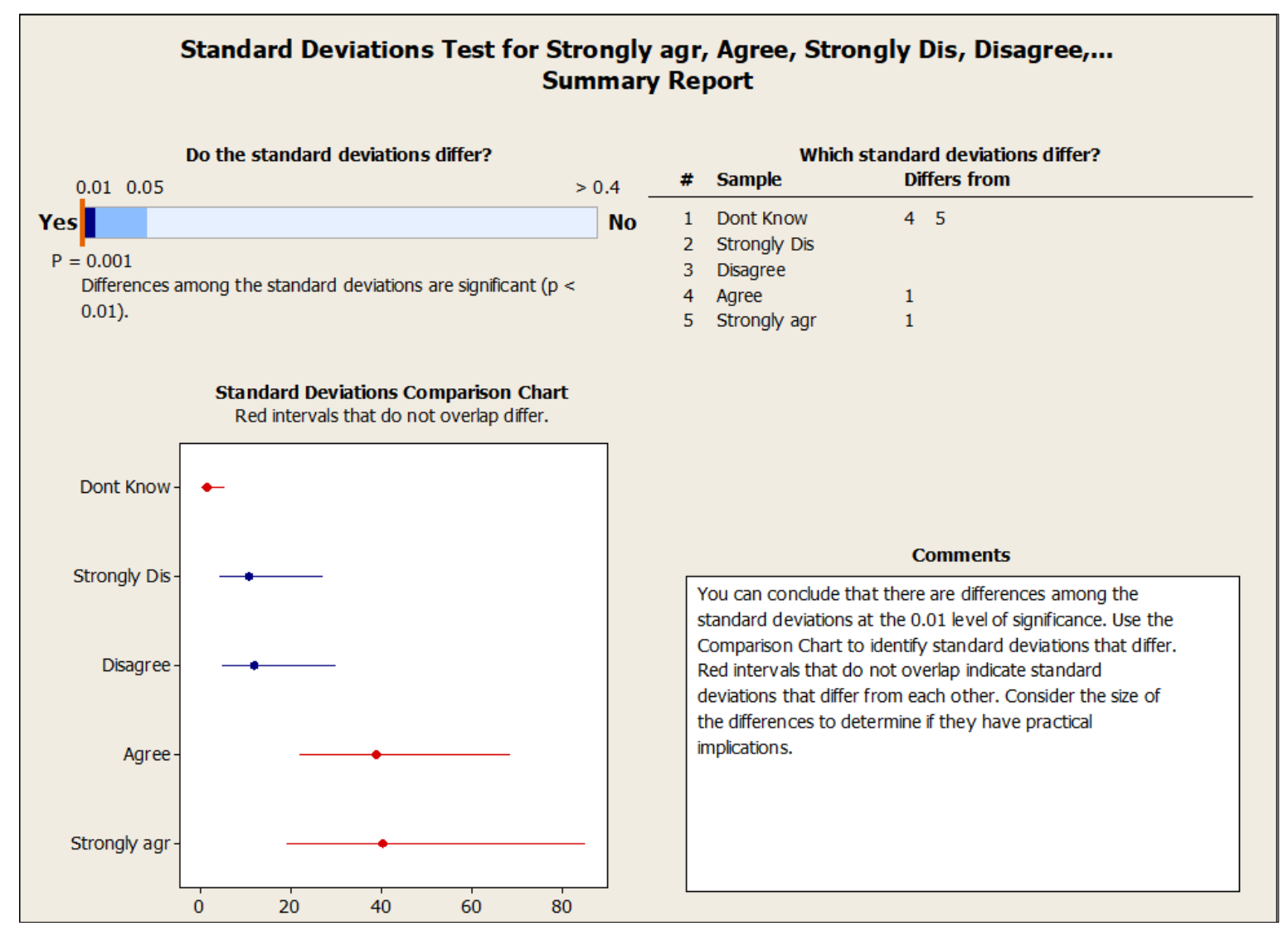

Figure 3 Summary Report for Standard Deviations Test

Figure 2 shows the diagnostic report for the standard deviation test. The statistical method was used to analyze the parameters. The analyses ensure the validity and compare the data distribution of the samples which revealed that the samples are properly distributed. Diagnostic report for the standard deviation statistical method also revealed the interactions of the samples on data distribution.

Figure 3 shows the summary report for the standard deviation test. The statistical method used to analyze the parameters. The analysis described the significance difference from the target percentages with significance level that is less than 0.05 . The outcome comparism chat reveals the shapes of the percentages profiles and shows which outcomes differ from the target count. However, the probability value for the test is accurate and has a significance value of 0.001 . Furthermore, it'sconcluded that there are differences among the standard deviations at the 0.001 level of significance.

Pearson correlations expressed that strongly agree and agree are significance with significance level of 0.024 , while that strongly disagree and disagree are not significance with significance level of 0.228 . This shows that the company's performance impact of tactical management practices are significance in construction companies.

\section{Discussions}

The research is based on evaluation of strategic management practices and their impact in construction companies.

In mean likert analysis, it represents ranking of four (4) significant factors leading to Strategic Management Practices in Construction companies. The result revealed the significance of tactical Management Practices in Construction Companies. The significance benefit of strategic management practices in construction companies ranked first among the factors with mean scores of 4.15 followed by the significance the effect of portfolio analysis on performance of construction companies with mean scores of 4.51. The motivational impact as a management tactics in construction companies ranked third, with mean scores of 4.16. The current benefit in adoption of corporate strategic management practices in construction companies ranks forth on the list with mean score of 4.29. This implies that there is a high significance on the effectiveness of tactical management practices on the performance of construction companies. 
The summary report for the standard deviation test described the significance difference from the target percentages with significance level that is less than 0.05 . The outcome comparism chat reveals the shapes of the percentages profiles and shows which outcomes differ from the target count. However, the probability value for the test is accurate and has a significance value of 0.001 . Furthermore, it'sconcluded that there are differences among the standard deviations at the 0.001 level of significance.The results reveal that the responses of the survey questionnaires concur that strategic management practices are highly significance in construction companies.

Furthermore, Pearson correlations expressed that strongly agree and agree are significance with significance level of 0.024 , while that strongly disagree and disagree are not significance with significance level of 0.228 . This shows that the company's performance impact of tactical management practices are significance in construction companies

\subsection{Summary of key Findings}

- Construction companies perform work inspections in strategic management practices.

- Construction companies accept express labour and contracting out or out-sourced methods in executing maintenance works.

- In construction companies, the method of implementation of management practices depends on management decision, availability of funds, equipment and skills.

- Strategic management practices are part of design and supervision team to completion of projects.

- In Construction Companies, they can conduct Staff training and continuous development programmes for strategic management staff lacking in the construction companies

- Sources of funds for strategic management practices in the construction companies are from Non-government, Government and donations.

- Poor strategic management practices of buildings affect the performance of stakeholders and worker's productivity in construction companies

- adoption of corporate strategic management practices is of benefit in construction companies

- $\quad$ strategic management practices is of benefit in construction companies

- motivational impact as a management tactics in construction companies

\section{Conclusion}

This research evaluated strategic management practices in Construction companies. The research was carried out in Anambra state, south east Nigeria. The research expressed that tactics or the strategy for management practices is the key in construction companies. This revealed that management practices are highly effective in construction companies. Therefore, without adequate tactical management practices, construction companies will have problems in design, construction and construction management specifically companies in the aforementioned case study. Having achieved the aim of the research which is to study the effectiveness of tactical management practices in construction companies in the aforementioned case study, the researcher however, recommends for wider use and applicability of the research output.

\section{Compliance with ethical standards}

\section{Acknowledgments}

The author wishes to acknowledge himself for the efforts applied in making this research article a huge success.

\section{Statement of informed consent}

The studied construction companies used in Anambra State gave their consent for the oral interview, survey, study, information, walk around observations and respondents questionnaires from their construction companies. The author also gives his consent for the paper publication in your establishment.

\section{References}

[1] Chaffee E. (1985). "Three models of strategy", Academy of Management Review. 1985; 10(1).

[2] Chitkara KK. (1988). Construction Project Management, New Delhi: Tata McGraw-Hill Education. $1998 ; 4$. 
[3] Compare (2016): "Construction". Merriam-Webster.com, Merriam-Webster, retrieved 2016-02-16, the act or process of building something (such as a house or road). 2016.

[4] Ezeliora C. D.; Nwakobi J. O., Aguh S. P. (2017): Appraisal of Optimal Production Quantity in Small and Medium Scale Industry; International Journal of Advanced Engineering Research and Technology (IJAERT) Volume 5 Issue 1, January 2017, ISSN No.: 2348 -8190; www.ijaert.org

[5] Ezeliora C. D.; Okoye P. C. \& Mbabuike I. U. M. (2019). Prediction and Optimization of Production Quantities in Innoson Manufacturing Extraction Plastic Product. Journal of Engineering Research and Reports, 6(2), 1-11. Retrieved from http://www.journaljerr.com/index.php/JERR/article/view/16947

[6] Ezeliora C. D.; Umeh M. N.; Mbeledeogu N. N.; Ezeokonkwo J. U. (2014): Improving the productivity of small and medium scale industries using linear programming model: International Journal of Scientific \& Engineering Research, Volume 5, Issue 1, January-2014 ISSN 2229-5518; pg 2009-2025

[7] Ezeliora C.D.; Umeh M. N. and Dilinna A. M. (2020) Investigation and Optimization of Production Variables: A Case of Plastic Manufacturing Industry. Journal of Engineering Research and Reports 15(1): 1-16, 2020; Article no.JERR.56495; ISSN: 2582-2926; DOI: 10.9734/JERR/2020/v15i117134

[8] Ghemawat, Pankaj. (2002) "Competition and Business Strategy in Historical Perspective". Business History Review. Harvard Business Review.2002.

[9] Halpin Daniel W, Senior, Bolivar A. (2010); Construction Management (4 ed.), Hoboken, NJ: John Wiley \& Sons.2010; 6.

[10] Hill Charles WL, Gareth R Jones. (2012) Strategic Management Theory: An Integrated Approach, Cengage Learning, 10th edition. 2012.

[11] Kotter, John. (1982). The general manager, Free Press, New York. 1982.

[12] Lamb, Robert (1984). Boyden Competitive strategic management, Englewood Cliffs, NJ: Prentice-Hall. 1984.

[13] Mintzberg, Henry and, Quinn, J. Brian (1996).The Strategy Process:Concepts, Contexts, Cases. Prentice Hall.. ((1982). Maintenance of Public Estates in Awka, Anambra State.(A case study of Iyiagu and Real Housing Estate.(Unpublished M.Sc Thesis), Nnamdi Azikiwe University Awka, Nigeria.2008.

[14] Ogunoh A. V.; Ezeliora C. D.; Okoye P. U.; Umeh M. N. (2014): Simulation of Waiting Line System Using Single-Line Multiple-Channel Models: A Case Study of NNPC Mega Stations in Owerri and Enugu State, Nigeria: International Journal of Scientific Engineering and Research (IJSER) ISSN (Online): 2347-3878 Volume 2 Issue 7, July 2014 Pg 27-34

[15] Porter, M, E. ((19896. "What is Strategy?" Harvard Business Review (November-December 1996). 